\title{
ANALISIS KINERJA KEUANGAN : KEMAMPUAN BANK SYARIAH DALAM PENYALURAN PEMBIAYAAN
}

\begin{abstract}
Abstrak
Penelitian ini bertujuan untuk menguji pengaruh faktor-faktor kinerja keuangan Bank Syariah dalam melakukan penyaluran pembiayaan, yaitu Dana Pihak Ketiga (DPK), Return on Asset (ROA), Capital Adequacy Ratio (CAR), dan Non Performing Financing (NPF). Penelitian ini mengacu penelitian sebelumnya mengenai penyaluran pembiayaan. Akan tetapi, objek penelitian sebelumnya merupakan Bank Konvensional yang prinsip pembiayaannya berbeda dengan Bank Syariah. Meskipun demikian, ada beberapa penelitian terdahulu mengenai penyaluran pembiayaan di Bank Syariah, namun belum terlalu banyak dilakukan. Oleh sebab itu, penelitian ini dilakukan untuk menjelaskan lebih dalam faktor yang mempengaruhi Bank Syariah dalam melakukan penyaluran pembiayaan. Penelitian ini menggunakan sampel sebanyak 9 Bank Syariah yang berada di Indonesia dengan periode tahun 2010-2015, sehingga diperoleh sampel sebanyak 54. Teknik pengambilan sampel menggunakan purposive sampling dengan teknik analisis regresi linier berganda untuk menguji hipotesis. Hasil penelitian menunjukkan bahwa Dana Pihak Ketiga (DPK) dan Non Performing Financing (NPF) berpengaruh secara signifikan terhadap penyaluran pembiayaan Bank Syariah. Sedangkan Return on Asset (ROA) dan Capital Adequacy Ratio (CAR) tidak berpengaruh terhadap penyaluran pembiayaan Bank Syariah.
\end{abstract}

Keywords : Pembiayaan, NPF, CAR, ROA, DPK.

\section{PENDAHULUAN}

Sektor perbankan syariah merupakan lembaga keuangan yang memiliki peran strategis dalam sistem keuangan yang didasarkan pada prinsip syariah, yaitu menjadi lembaga intermediasi keuangan yang menghimpun Dana Pihak Ketiga (DPK) dan menyalurkannya kembali dalam bentuk pembiayaan secara efektif dan efisien. Pendirian Bank Syariah bertujuan untuk mengenalkan dan mengembangkan penerapan prinsip Islam, dan tradisinya ke dalam transaksi keuangan dan perbankan.

Meningkatnya pertumbuhan ekonomi, berpengaruh pada perkembangan perbankan syariah. Hal ini ditunjukkan dari peningkatan total aset dari 11 Bank Syariah di Indonesia pada triwulan IV tahun 2015 yang mengalami peningkatan sebesar Rp 23.919 miliar atau sebesar 8,78\% dari tahun sebelumnya. Sedangkan dari segi pembiayaan, pada bulan Desember 2015 memiliki nilai sebesar Rp 212.996 miliar, yang berarti perbankan syariah mengalami peningkatan pembiayaan sebesar 6,86\% atau sebesar $\mathrm{Rp} 13.666$ miliar dari tahun sebelumnya. Hal ini bisa dilihat dari besarnya Non Performing Financing (NPF) perbankan syariah di tahun 2015 yang berada di bawah nilai 5\%, yaitu sebesar 4,34\%.

Selain Non Performing Financing (NPF) yang dapat berpengaruh terhadap kualitas pembiayaan perbankan syariah adalah nilai Dana Pihak Ketiga (DPK). Hal ini disebabkan semakin besar nilai DPK perbankan syariah, maka semakin meningkat pula penyaluran pembiayaan. Dalam hal ini, besarnya nilai DPK perbankan syariah di tahun 2015 meningkat seiring dengan meningkatnya pembiayaan perbankan syariah, yaitu meningkat 
sebesar $6,11 \%$ dari tahun sebelumnya.

Selanjutnya, perkembangan lain yang terjadi pada perbankan syariah adalah meningkatnya Return on Asset (ROA), yaitu sebesar 1,68\% pada tahun 2015. Hal ini mengindikasi bahwa perbankan syariah mampu mengelola aset dengan baik dan mampu menginvestasikan keuntungan tersebut dalam bentuk penyaluran pembiayaan. Kemudian, jika dilihat dari nilai Capital Adequacy Ratio (CAR) pada perbankan syariah tahun 2015, nilai tersebut mengalami sedikit penurunan dari tahun sebelumnya menjadi 15,01\%. Akan tetapi, nilai CAR perbankan syariah masih dalam kondisi yang baik walaupun terjadi sedikit penurunan. Kondisi tersebut dibuktikan dengan meningkatnya pembiayaan perbankan syariah, yang berarti tingkat kecukupan modal yang dimiliki perbankan syariah sudah cukup baik.

Kajian mengenai tingkat kinerja perbankan telah banyak dilakukan, baik dilakukan di bank konvensional maupun di bank syariah. Beberapa peneliti yang telah melakukan penelitian mengenai kinerja perbankan antara lain Meliyanti (2008), Prasnanugraha (2007), Nandadipa (2010), Triasdini (2010), Pratami (2011), Oktaviani (2012), dan Adzimatinur (2013).

\section{LANDASAN TEORI}

\section{Perbankan Syariah}

Bank Syariah merupakan lembaga keuangan yang memiliki tugas pokok untuk memberikan pembiayaan dan jasa lainnya dalam lalu lintas pembayaran serta peredaran uang yang pelaksanaannya harus sesuai dengan prinsip syariat Islam. Menurut Undang-Undang Nomor 21 Tahun 2008 tentang Perbankan Syariah, menyebutkan bahwa bank syariah adalah bank yang melaksanakan aktivitas usahanya berlandaskan prinsip syariah yang terdiri atas Bank Umum Syariah dan Bank Pembiayaan Rakyat Syariah.

\section{Pembiayaan Syariah}

Berdasarkan UU Nomor 10 Tahun 1998 tentang Perbankan Syariah, pembiayaan syariah adalah kegiatan menyediakan uang dan tagihan yang didasarkan pada kesepakatan antara bank dengan nasabah serta mengharuskan nasabah yang didanai untuk mengembalikan uang atau tagihan tersebut dalam jangka waktu tertentu dengan imbalan atau bagi hasil.

Pratami (2011) menyatakan bahwa pembiayaan adalah pendanaan yang dikeluarkan guna mendukung modal kerja yang telah direncanakan, baik yang dijalankan sendiri maupun dijalankan oleh orang lain. Dalam arti sempit, pembiayaan digunakan untuk mendefinisikan pendanaan yang dilaksanakan oleh lembaga pembiayaan kepada nasabah untuk modal kerja atau investasi.

\section{Dana Pihak Ketiga (DPK)}

Berdasarkan UU No. 21 Tahun 2008 tentang Perbankan Syariah, menjelaskan bahwa simpanan merupakan dana yang dipercayakan oleh nasabah kepada Bank Syariah berdasarkan akad wadi'ah atau akad lain yang sesuai dengan prinsip syariah yang berupa Giro, Tabungan, atau bentuk lainnya. Dana dari masyarakat yang 
disimpan dalam bank dan merupakan sumber dana terbesar yang sangat diandalkan adalah Giro, Tabungan, dan Deposito.

\section{Capital Adequacy Ratio (CAR)}

Peraturan BI Nomor 3/21/PBI/2001, menyatakan bahwa bank wajib menyediakan modal minimum sebesar $8 \%$ dari aktiva tertimbang menurut resiko yang digambarkan dalam bentuk Capital Adequacy Ratio (CAR). Perhitungan CAR dilakukan untuk setiap penanaman dalam bentuk pembiayaan yang memiliki resiko maka Bank Syariah harus memiliki sejumlah modal yang disesuaikan dengan presentase tertentu sesuai jumlah penanamannya tersebut (Budiawan, 2008). CAR digunakan untuk memastikan apabila bank mengalami kerugian dalam pelaksanaan kegiatannya, maka ketersediaan modal yang dimiliki oleh bank syariah mampu menutup kerugian tersebut (Triasdini, 2010).

\section{Non Performing Financing (NPF)}

Non Performing Financing (NPF) digunakan sebagai indikator yang menggambarkan kerugian akibat resiko pembiayaan. Non Performing Financing (NPF) merupakan rasio antara pembiayaan bermasalah dengan total pembiayaan yang diberikan oleh bank syariah. Berdasarkan kriteria yang telah ditetapkan oleh Bank Indonesia, kategori NPF mencakup pembiayaan kurang lancar, pembiayaan yang diragukan, dan pembiayaan macet.

\section{Return on Asset (ROA)}

Return on Asset (ROA) adalah rasio yang digunakan untuk mengetahui kemampuan bank dalam menghasilkan laba di masa lalu. Analisis ROA dapat digunakan sebagai gambaran ke masa mendatang untuk melihat kemampuan bank dalam menghasilkan profit. Menurut Bank Indonesia, dalam menilai kesehatan bank, bank akan memperoleh skor maksimum 100 jika bank memiliki nilai ROA sebesar 1,5\%. Jika rasio ROA suatu bank meningkat, maka meningkat pula tingkat laba yang akan diraih bank tersebut dan semakin baik posisi bank tersebut dari segi pengamanan aset (Dendawijaya, 2003).

\section{PENGEMBANGAN HIPOTESIS}

\section{Pengaruh Dana Pihak Ketiga (DPK) Terhadap Pembiayaan}

Aktivitas utama sektor perbankan adalah menghimpun dana dari masyarakat dan menyalurkannya kembali ke masyarakat dalam bentuk pembiayaan. Dana yang dihimpun atau disimpan oleh perbankan dapat berupa Giro, Tabungan, dan Deposito. Dana yang dihinpun oleh bank dalam bentuk Dana Pihak Ketiga (DPK) merupakan sumber dana terbesar yang paling diandalkan dalam kegiatan bank (Dendawijaya, 2005). Aktivitas bank setelah menghimpun dana dari masyarakat adalah menyalurkan kembali dana tersebut dalam bentuk pembiayaan (Kasmir, 2008). Berdasarkan pernyataan diatas, maka hipotesis yang dapat diambil adalah:

H1 : Dana Pihak Ketiga (DPK) berpengaruh positif terhadap pembiayaan. 


\section{Pengaruh Capital Adequacy Ratio (CAR) Terhadap Pembiayaan}

Capital Adequacy Ratio (CAR) adalah rasio permodalan yang menggambarkan kemampuan bank dalam menyediakan dana untuk pengembangan modal kerja dan menampung resiko kerugian tersebut karena aktivitas operasi bank (Ali, 2004). Tingginya rasio CAR, mengakibatkan tingkat kepercayaan bank dalam menyalurkan pembiayaan karena bank mampu mengantisipasi potensi kerugian yang diakibatkan oleh penyaluran pembiayaan juga tinggi. Oleh sebab itu, hipotesis yang dapat diambil adalah:

\section{H2 : Capital Adequacy Ratio (CAR) berpengaruh positif terhadap pembiayaan.}

\section{Pengaruh Non Performing Financing (NPF) Terhadap Pembiayaan}

Non Performing Financing (NPF) mencerminkan tingkat resiko kredit bank. Semakin tinggi tingkat NPF, maka semakin tinggi tingkat resiko kredit yang dimiliki oleh bank. Oleh sebab itu, tingginya tingkat NPF menjadi salah satu penyebab sulitnya bank dalam menjalankan kegiatan penyaluran pembiayaan (Sentausa, 2009). Dengan demikian, hipotesis yang dapat diambil adalah:

H3: Non Performing Financing (NPF) berpengaruh negatif terhadap pembiayaan.

\section{Pengaruh Return on Asset (ROA) Terhadap Pembiayaan}

Return on Asset (ROA) adalah rasio yang digunakan untuk melihat kemampuan bank untuk mendapatkan laba yang dilihat dari aset yang dimiliki. Meningktanya nilai ROA, maka tingkat laba yang didapatkan dari penggunaan aset yang dimiliki juga semakin meningkat. ROA digunakan karena Bank Indonesia lebih memprioritaskan profitabilitas bank yang dinilai dari sebagian besar dana yang diperoleh dari masyarakat, yang selanjutnya dana tersebut disalurkan kembali ke masyarakat dalam bentuk pembiayaan. Berdasarkan pernyataan di atas, hipotesis yang dapat diambil adalah:

H4: Return on Asset (ROA) berpengaruh positif terhadap pembiayaan.

\section{METODE PENELITIAN}

\section{Variabel Penelitian}

Penelitian ini berusaha untuk menjelaskan faktor-faktor yang berpengaruh terhadap penyaluran pembiayaan perbankan syariah di Indonesia. Dimana faktor tersebut meliputi Dana Pihak Ketiga (DPK), Capital Adequacy Ratio (CAR), Non Performing Financing (NPF), dan Return on Asset (ROA) sebagai variabel independen. Sedangkan penyaluran pembiayaan perbankan syariah di Indonesia sebagai variabel dependen.

\section{Definisi Operasional Variabel}

\section{Dana Pihak Ketiga (DPK)}

Simpanan merupakan dana yang dipercayakan oleh masyarakat kepada bank yang didasarkan dengan perjanjian penyimpanan dana berupa deposito, giro, tabungan dan atau bentuk lain yang dipersamakan dengan itu (Maharani, 2010). Dengan demikian, rumus untuk menghitung DPK adalah

DPK = Giro + Deposito + Tabungan 


\section{Capital Adequacy Ratio (CAR)}

Capital Adequacy Ratio (CAR) merupakan rasio yang menggambarkan seberapa jauh semua aset bank yang mengandung resiko, baik pembiayaan, surat berharga, penyertaan, dan tagihan pada bank lain, ikut didanai dari modal sendiri bank ditambah dengan dana-dana dari sumber di luar bank, seperti dana dari masyarakat, pinjaman (utang), dan sebagainya (Dendawijaya, 2003).

$$
\mathrm{CAR}=\frac{\text { Modal Bank }}{\text { Total } \Lambda \mathrm{TMR}} \times 100 \%
$$

\section{Non Performing Financing (NPF)}

Non Performing Financing (NPF) merupakan rasio yang berasal dari perbandingan antara pembiayaan bermasalah dan total pembiayaan yang disalurkan oleh bank syariah (Triasdini, 2010). Rumus untuk mengetahui nilai NPF adalah sebagai berikut :

$$
\mathrm{NPF}=\frac{\text { Pembiayaan Bermasalab }}{\text { Total Penbiayaan }} \times 100 \%
$$

\section{Return on Asset (ROA)}

Return on Asset (ROA) merupakan rasio yang menilai kemampuan bank menghasilkan profit di masa lalu. Rumus ROA menurut ketentuan Bank Indonesia adalah sebagai berikut :

$$
\text { ROA }=\frac{\text { Laba setelab bunga dan pajak }}{\text { Total } \Lambda \text { set }}
$$

\section{Populasi dan Sampel}

Populasi yang termasuk dalam penelitian ini adalah seluruh Bank Syariah di Indonesia. Sedangkan sampel yang diambil dalam penelitian ini adalah 9 Bank Syariah yang berada di Indonesia dengan periode tahun 20102015. Teknik pengambilan sampel dalam penelitian ini menggunakan purposive sampling, dengan kriteria, yaitu Bank Syariah yang melaporkan pembiayaan secara teratur dalam Laporan Tahunan periode 2010-2015.

\section{Metode Pengumpulan Data}

Pengumpulan data dilakukan dengan cara mengumpulkan data, mencatat, kemudian mengkaji data sekunder yang terdapat dalam Laporan Tahunan dari 9 Bank Syariah yang menjadi sampel penelitian mulai periode 2010-2015.

\section{Statistik Deskriptif}

Statistik deskriptif digunakan untuk mengetahui gambaran variabel-variabel yang ada dalam penelitian. Statistik deskriptif menggambarkan suatu data yang dinilai dari rata-rata, standar deviasi, nilai minimum dan nilai maksimum dari variabel-variabel yang diteliti. 
Uji Asumsi Klasik

Pengujian asumsi klasik dalam penelitian ini terdiri dari uji normalitas, uji multikolinearitas, uji heterokedastisitas, dan uji autokorelasi yaitu :

Uji normalitas digunakan untuk mengetahui apakah data dalam variabel penelitian terdistribusi normal. Uji normalitas bisa diketahui dengan menggunakan uji Kolmogorov Smirnov. Dimana data dikatakan normal apabila nilai signifikansinya lebih dari 0,05.

Uji multikolinearitas digunakan untuk menguji model regresi ditemukan adanya korelasi antar variabel independen. Ghozali (2009) mengatakan bahwa jika nilai tolerence lebih dari 0,1 dan nilai VIF yang tidak lebih dari 10 maka hubungan linear diantara variabel-variabel bebas dalam model regresi tidak mengandung multikolinearitas.

Uji heterokedastisitas memiliki tujuan untuk menguji model regresi linier terjadi ketidaksamaan varian dari residual satu pengamatan ke lainnya.

Uji Autokorelasi memiliki tujuan untuk menguji model regresi linier memiliki hubungan antara kesalahan pengganggu pada periode t dengan kesalahan pengganggu pada periode t-1 (Ghozali, 2009).

\section{Pengujian Hipotesis}

Uji hipotesis dalam penelitian ini menggunakan uji regresi linear berganda, dengan cara melihat nilai pada uji t dan $p$-value. Uji t digunakan untuk melihat pengaruh variabel dependen dan variabel independen secara individual, dengan membandingkan nilai probabilitas. Jika $P$-value $>0,05$ maka $\mathrm{H} 0$ diterima, yaitu tidak ada pengaruh signifikan antara variabel dependen dan independen. Jika $P$-value $<0,05$, maka H0 ditolak, yaitu ada pengaruh signifikan antara variabel dependen dan independen (Ghozali, 2009).

\section{HASIL DAN PEMBAHASAN}

Populasi dalam penelitian ini merupakan semua Bank Syariah di Indonesia. Jumlah Bank Syariah yang menjadi objek penelitian digambarkan dalam tabel1.

Berdasarkan hasil statistik deskriptif yang digambarkan dalam Tabel 2, diperoleh nilai minimum, maksimum, rata - rata (mean), dan standar deviasi (standard deviation) dari masing-masing variabel penelitian.

\section{Pengujian Asumsi Klasik}

Berdasarkan hasil uji normalitas dengan analisis Kolmogorov - Smirnov (K-S) diperoleh hasil bahwa variabel DPK, ROA, NPF dan CAR memiliki tingkat signifikansi (0.156) lebih besar dari 0,05. Dengan demikian, disimpulkan bahwa data dalam penelitian ini terdistribusi secara normal.

Uji Multikolonieritas bertujuan untuk melihat apakah dalam model regresi ditemukan adanya hubungan antar variabel bebas (independen). Model regresi yang baik semestinya tidak terjadi hubungan diantara variabel independen (Ghozali, 2009). Berdasarkan hasil Uji Multikolonieritas didapatkan hasil bahwa variabel DPK, ROA, NPF dan CAR bebas dari multikolonieritas dengan nilai tolerance $>0,10$ atau nilai VIF $<10$. 
Berdasarkan hasil Uji Heteroskedastisitas dengan menggunakan uji Glejser menyatakan bahwa variabel DPK, ROA, NPF dan CAR bebas dari heteroskedastisitas yang digambarkan dengan tingkat signifikansi > 0,05. Sedangkan berdasarkan hasil Uji Autokorelasi yang disebutkan dalam Tabel 5, menggambarkan bahwa nilai Durbin-Watson sebesar 0.446.

\section{Pengujian Hipotesis}

Hasil uji hipotesis mengunakan regresi linier berganda ditunjukan dengan tabel 6. Berdasarkan uji hipotesis ditemukan bahwa variable DPK berpengaruh positif signifikan terhadap pembiayaan dengan nilai koefisien sebesar 1.058 dengan nilai signifikansi 0.000 . Hal ini menggambarkan bahwa semakin tinggi nilai DPK yang berhasil dihimpun oleh perbankan, akan meningkatkan jumlah pembiayaan yang disalurkan, demikian pula sebaliknya. Pembiayaan merupakan salah satu kegiatan utama bank dalam pengalokasian dananya. Hal ini disebabkan sumber dana utama bank diperoleh dari masyarakat, sehingga bank diwajibkan menyalurkan kembali DPK yang berhasil dihimpun kepada masyarakat dalam bentuk pembiayaan. Hal ini selaras dengan fungsi bank sebagai perantara keuangan (financial intermediary).

DPK merupakan sumber pendanaan yang utama bagi Bank Syariah dan memiliki pengaruh terbesar dalam penyaluran pembiayaan perbankan. Dana yang dihimpun dari masyarakat dapat mencapai $80 \%-90 \%$ dari keseluruhan dana yang dikelola oleh bank syariah (Dendawijaya, 2005).

Hasil penilaian selanjutnya yaitu variabel ROA. Dimana dari hasil diatas diketahui bahwa nilai ROA tidak berpengaruh terhadap pembiayaan dengan nilai koefisien sebesar 665289.681 dengan nilai signifikansi sebesar $0.736>0,05$. ROA sebagai ukuran tingkat keuntungan yang memadai akan mampu meningkatkan penganggaran volume pembiayaan bank syariah, namun dalam hasil penelitian tidak signifikan.

Variabel NPF berpengaruh negatif signifikan terhadap pembiayaan dengan nilai koefisien sebesar-1.295E8 dengan nilai signifikansi $0.003<0,05$. Hasil ini menunjukkan bahwa meningkatnya nilai NPF akan berakibat pada hilangnya kesempatan memperoleh pendapatan (income) dari pembiayaan yang diberikan. Hal itu berakibat pada laba yang semakin berkurang karena Bank Syariah memiliki tingkat pembiayaan bermasalah yang besar, sehingga dapat mengurangi kemampuan Bank Syariah dalam memberikan pembiayaan.

Variabel CAR berpengaruh negatif namun tidak signifikan terhadap pembiayaan dengan nilai koefisien sebesar -2.509E6 dengan nilai signifikansi sebesar $0.691<0,05$. Hasil penelitian ini mengindikasikan bahwa nilai CAR tidak berpengaruh terhadap jumlah pembiayaan yang diberikan oleh Bank Syariah. Hal ini dikarenakan, Bank Syariah dalam memberikan pembiayaan, akan lebih melihat pada nilai NPF dibanding dengan nilai CAR. Apabila dirasa nilai NPF itu tinggi, berarti ada permasalahan dalam hal pembiayaan, sehingga Bank Syariah akan berpikir ulang untuk menambah pembiayaan yang disalurkan.

\section{KESIMPULAN}

Penelitian ini didasarkan pada pentingnya pemahaman mengenai faktor-faktor yang mempengaruhi penyaluran pembiayaan di Bank Syariah. Faktor-faktor tersebut antara lain, Non Performing Financing (NPF), Dana Pihak Ketiga (DPK), Capital Adequacy Ratio (CAR), dan Return on Asset (ROA). Semua variabel tersebut 


\section{JURNAL AKUNTANSI INDONESIA}

akan berpengaruh terhadap penyaluran pembiayaan di bank syariah. Pengujian hipotesis dalam penelitian ini berhasil mendukung 2 hipotesis yang diajukan, yaitu $\mathrm{H} 1$ dan $\mathrm{H} 3$, namun tidak mendukung hipotesis $\mathrm{H} 2$ dan H4. Data penelitian diperoleh melalui pengamatan dan pengujian dari laporan tahunan bank syariah periode 2010-2015 dan diperoleh sampel sebanyak 54. Selanjutnya, penelitian ini menggunakan teknik regresi linier berganda untuk menguji hipotesis tersebut.

Jurnal Akuntansi Indonesia 


\section{DAFTAR PUSTAKA}

Adzimatinur, Fauziyah, Sri Hartoyo, Ranti Wiliasih. (2011). Factors Affecting The Amount of Financing Islamic Banking in Indonesia. Jurnal Al-Muzara'ah. Page 106-122.

Alamsyah, Halim Dr. (2012). Perkembangan dan Prospek Perbankan Syariah Indonesia : Tantangan Dalam Menyongsong MEA 2015. Ceramah IImiah Ikatan Ahli Ekonomi Islam (IAEI).

Budiawan. (2008). Analisis Faktor-Faktor yang Mempengaruhi Penyaluran Kredit pada BPR di Wilayah Kerja BI Banjarmasin. Tesis .

Dendawijaya, L. (2003). Manajemen Perbankan. Jakarta: Ghalia Indonesia.

Ghozali, I. (2009). Aplikasi Analisis Multivariate dengan Program SPSS. Semarang: Badan Penerbit Universitas Diponegoro.

Nandadipa, Seandy. (2010). Analisis Pengaruh CAR, NPL, Inflasi, Pertumbuhan DPK, dan Exchange Rate Terhadap LDR. Skripsi.

Maharani, S. D. (2010). Analisis Pengaruh CAR, NPF, dan DPK Terhadap Penyaluran Pembiayaan. Skripsi .

Meliyanti, Nuresya. (2015). Analisis Kinerja Keuangan Bank : Pendekatan Rasio NPL, LDR, BOPO, dan ROA Pada Bank Privat dan Publik.

Oktaviani. (2012). Pengaruh DPK, ROA, CAR, NPL, dan Jumlah SBI Terhadap Penyaluran Kredit Perbankan. Skripsi.

Prasnanugraha, Ponttie. (2007). Analisis Pengaruh Rasio-Rasio Keuangan Terhadap Kinerja Bank Umum di Indonesia. Skripsi.

Pratama, Billy Arma. (2010). Analisis Faktor-Faktor Yang Mempengaruhi Kebijakan Penyaluran Kredit Perbankan. Thesis.

Pratami, W. A. (2011). Analisis Pengaruh Dana Pihak Ketiga (DPK), Capital Adequacy Ratio (CAR), Non Performing Financing (NPF) dan Return on Asset (ROA) Terhadap Pembiayaan Pada Perbankan Syariah. Skripsi .

Triasdini, H. (2010). Pengaruh CAR, NPL, dan ROA Terhadap Penyaluran Kredit Modal Kerja. Skrispi . 
Tabel 1

Daftar Bank Syariah

\begin{tabular}{|l|}
\hline \multicolumn{1}{|c|}{ Nama Bank } \\
\hline BSM \\
\hline BNI Syariah \\
\hline BRI Syariah \\
\hline BCA Syariah \\
\hline Bank Mega Syariah \\
\hline Bank Bukopin Syar \\
\hline Bank Jabar Syariah \\
\hline Bank Panin Syariah \\
\hline Bank Muamalat \\
\hline
\end{tabular}

Tabel 2

Statistik Deskriptif

\begin{tabular}{|l|r|r|r|r|r|r|}
\hline & \multicolumn{1}{|c|}{$\mathrm{N}$} & \multicolumn{1}{|c|}{ Minimum } & Maximum & \multicolumn{2}{|c|}{ Mean } & \multicolumn{1}{c|}{ Std. Deviation } \\
\hline & Statistic & \multicolumn{1}{c|}{ Statistic } & \multicolumn{1}{c|}{ Statistic } & Statistic & \multicolumn{1}{c|}{ Std. Error } & \multicolumn{1}{c|}{ Statistic } \\
\hline Pembiayaan & 54 & $1.75 \mathrm{E} 5$ & $7.84 \mathrm{E} 7$ & $1.8770 \mathrm{E} 7$ & $2.87595 \mathrm{E} 6$ & $2.11338 \mathrm{E7}$ \\
\hline DPK & 54 & $2.95 \mathrm{E} 5$ & $6.33 \mathrm{E} 7$ & $1.9012 \mathrm{E} 7$ & $2.74277 \mathrm{E} 6$ & $2.01552 \mathrm{E7}$ \\
\hline ROA & 54 & -2.53 & .04 & -.0337 & .04712 & .34625 \\
\hline NPF & 54 & .00 & .07 & .0281 & .00249 & .01833 \\
\hline CAR & 54 & .11 & .76 & .2050 & .01750 & .12860 \\
\hline Valid N (listwise) & 54 & & & & & \\
\hline
\end{tabular}

Sumber: Data diolah (2017)

Tabel 3

One-Sample Kolmogorov-Smirnov Test

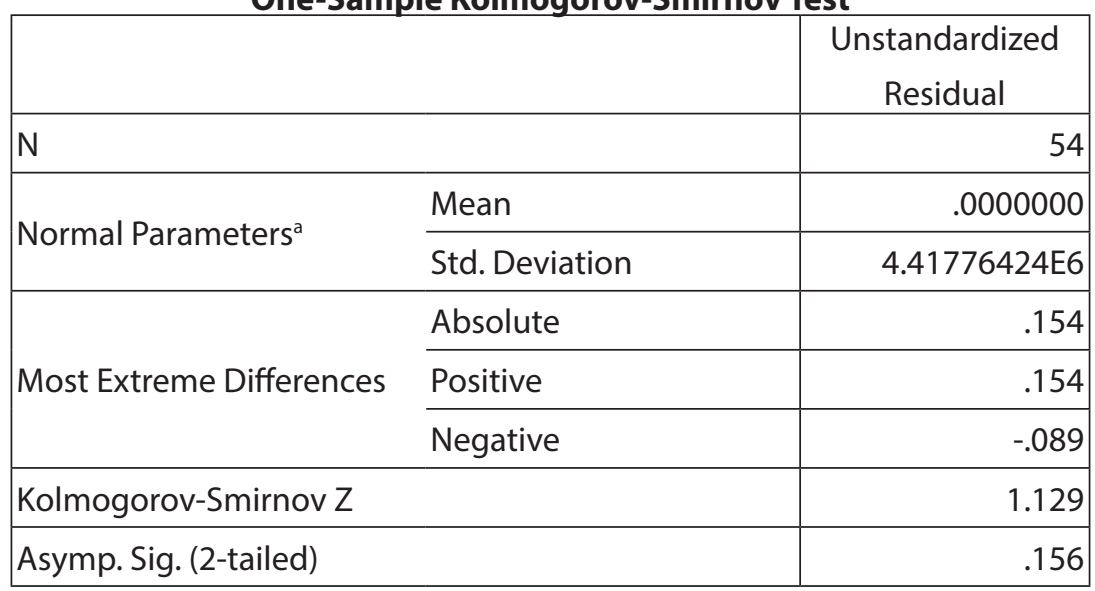

a. Test distribution is Normal.

Sumber: Data yang diolah (2017) 
Tabel 4

Coefficients $^{\mathrm{a}}$

\begin{tabular}{|c|c|}
\hline \multicolumn{2}{|c|}{ Collinearity Statistics } \\
\hline Tolerance & VIF \\
\hline .813 & 1.230 \\
\hline .862 & 1.161 \\
\hline .672 & 1.488 \\
\hline .612 & 1.633 \\
\hline
\end{tabular}

a. Dependent Variable: Pembiayaan

Sumber: Data yang diolah (2017).

Tabel 5

Model Summary ${ }^{b}$

\begin{tabular}{|l|r|r|r|r|r|}
\hline Model & \multicolumn{1}{|c|}{$\mathrm{R}$} & R Square & \multicolumn{1}{c|}{$\begin{array}{c}\text { Adjusted R } \\
\text { Square }\end{array}$} & $\begin{array}{c}\text { Std. Error of the } \\
\text { Estimate }\end{array}$ & Durbin-Watson \\
\hline 1 & $.978^{\mathrm{a}}$ & .956 & .953 & $4.59454 \mathrm{E} 6$ & .446 \\
\hline
\end{tabular}

a. Predictors: (Constant), CAR, ROA, DPK, NPF

b. Dependent Variable: Pembiayaan

Sumber : Data yang diolah (2017).

Tabel 6

Coefficients $^{\mathrm{a}}$

\begin{tabular}{|c|c|c|c|c|c|c|}
\hline \multirow{2}{*}{\multicolumn{2}{|c|}{ Model }} & \multicolumn{2}{|c|}{ Unstandardized Coefficients } & \multirow{2}{*}{\begin{tabular}{|c|}
$\begin{array}{c}\text { Standardized } \\
\text { Coefficients }\end{array}$ \\
Beta \\
\end{tabular}} & \multirow[t]{2}{*}{$\mathrm{t}$} & \multirow[t]{2}{*}{ Sig. } \\
\hline & & $\mathrm{B}$ & Std. Error & & & \\
\hline \multirow{5}{*}{1} & (Constant) & 2.834E6 & 2.265E6 & & 1.251 & .217 \\
\hline & DPK & 1.058 & .035 & 1.009 & 30.466 & .000 \\
\hline & $\mathrm{ROA}$ & 665280.681 & $1.964 \mathrm{E} 6$ & .011 & .339 & .736 \\
\hline & NPF & $-1.295 E 8$ & 4.199E7 & -.112 & -3.084 & .003 \\
\hline & CAR & $-2.509 \mathrm{E} 6$ & $6.271 \mathrm{E} 6$ & -.015 & -.400 & .691 \\
\hline
\end{tabular}

a. Dependent Variable: Pembiayaan

Sumber : Data yang diolah (2017). 